\title{
VITALIY IVANOVICH KARMAZIN CELEBRATES HIS 90th BIRTHDAY
}

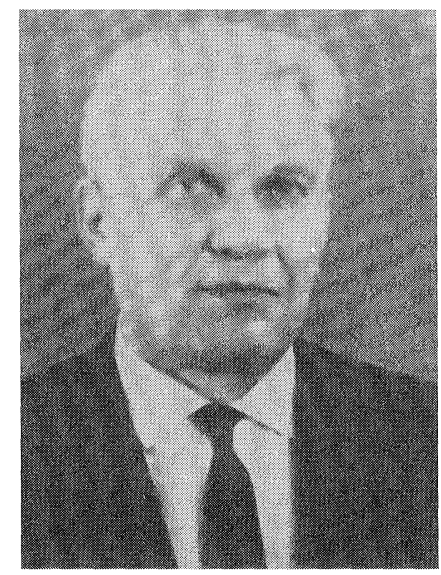

Vitaliy Ivanovich Karmazin, Doctor of Technical Sciences, Professor of the National Mining Academy of the Ukraine, Editor-in-chief of the national inter-departmental technological journal Dressing of mineral resources, Member of the editorial board of the international journal Magnetic and Electrical Separation, Scientific head of Department of Wet Magnetic Beneficiation, Research and Development Laboratory of the National Mining Academy of the Ukraine, is celebrating his 90th birthday.

The scientific and engineering activities of V.I. Karmazin, one of the scholars from the N.N. Dobrochotov and I.N. Plaksin school, are well known and widely recognised. He played a leading role in addressing problems of beneficiation of magnetite and oxidized quartzites, removal of sulphur from coal and gasification of metallurgical fuel. 
V.I. Karmazin developed modern methods of preliminary beneficiation and liberation of iron, manganese and chromite ores, wet magnetic separation of ores of rare metals, high intensity magnetic separation of ores and coal and production of concentrates from wastes of the metallurgical plants. He also contributed to the development of modern theories of mineral beneficiation.

Vitaliy Ivanovich Karmazin initiated development of techniques for the processing of ferrous quartzites as the head of the first preparation plant for Krivoy Rog magnetite quarzites, and then as the manager of the Department of Ore Processing SRMOI and the Deputy director of Research and Development at the Mechanobrchermet Institute. Vitaliy Ivanovich also participated in the development of the theory and practical solutions of magnetising roasting and high gradient separation using superconducting magnets. V.I. Karmazin has also been active as an educator as the Professor and the Head of the Department of Mineral Processing of the National Mining Academy of the Ukraine.

Vitaliy Ivanovich Karmazin, one of the leading scientists and researchers, and the founder of the magnetic beneficiation technology in Russia and Ukraine, is the author of more than 350 papers and 85 inventions and international patents. $\mathrm{He}$ is also the author of numerous monographs and textbooks. In 2001 he published the first textbook Magnetic and electrical methods of beneficiation in the Ukrainian language.

Separators, based on the inventions by V.I. Karmazin, have been, for many years, in operation in numerous beneficiation plants in Nicopol, Chiatury, Lisakovsk, Krivoy Rog and in Volnogorsk, Olenegorsk and other mining-and-metallurgical complexes.

Vitaliy Ivanovich, as a doyen of mineral treatment technology, supervised and mentored numerous engineers, post-graduate students and post-doctoral fellows and contributed to the increasing expertise of plant engineers at various mining operations. Well-known specialists, such as P.E. Ostapenko, A.I. Denisenko, V.V. Karmazin, P.A. Usachev, P.I. Zelenov, A.M. Turkenich, were among his students.

During the last few years, Professor Karmazin, in cooperation with the Gipromashugleobogaschenie Institute and the Moscow State Mining University, developed new technologies for underground beneficiation and concentration of ores with the objective to reduce negative environmental impact. 
Celebrating Vitaliy Ivanovich's anniversary, we wish him good health, personal happiness and continuing success in his fruitful scientific activities.

National Mining Academy of the Ukraine Moscow State Mining University Joint-stock Company Kovdorsky Mining-and-Beneficiation Complex Editorial Board of the Mining Journal (Russia) 